\title{
NUTRITIONAL VALUE AND TECHNOLOGICAL SUITABILITY OF MILK FROM COWS OF THREE POLISH BREEDS INCLUDED IN THE GENETIC RESOURCES CONSERVATION PROGRAMME*
}

\author{
Zygmunt Litwińczuk ${ }^{1}$, Joanna Barłowska², Witold Chabuz', \\ Aneta Brodziak ${ }^{1}$ \\ ${ }^{1}$ Department of Breeding and Genetic Resources Protection of Cattle, \\ ${ }^{2}$ Department of Commodity Science and Processing of Raw Animal Materials, \\ University of Life Sciences, Akademicka 13, 20-950 Lublin, Poland \\ Corresponding author: zygmunt.litwinczuk@up.lublin.pl
}

\begin{abstract}
The study included milk obtained from cows of three native cattle breeds, i.e. White-backed (BG), Polish Red (RP) and Polish Black-and-White (ZB) kept under conventional conditions. The reference group consisted of milk from Polish Holstein-Friesian cows (PHF) maintained in the intensive system and milk from Simmental cows (SM) kept under conventional conditions. The following parameters were determined in $\mathbf{9 7 6}$ samples of milk: content of fat, protein, casein, lactose and solids; acidity ( $\mathrm{pH}$ value); heat stability; rennet coagulation time; content of $\alpha$-lactalbumin, $\beta$-lactoglobulin, serum albumin, lactoferrin and lysozyme. Additionally, a certain proportion of samples was investigated for fatty acid profile and content of macro- and microelements. Cows of native breeds produced milk of higher nutritional value (higher content of whey proteins and polyunsaturated fatty acids, including CLA) and more suitable for processing as compared to PHF cows. Milk from cows of the Polish Red breed was the most valuable in terms of these parameters, which can be associated with a distinctive phylogenetic origin of this breed. The favourable parameters in regard to the nutritional value and technological suitability of milk obtained from analysed population of cows of 3 breeds included in the programme of genetic resources conservation are therefore an important reason of validity for subsequent implementation of this programme.
\end{abstract}

Key words: local cattle breeds, milk, nutritional value, technological suitability

Cow's milk is a good raw material for processing, including the manufacture of cheese. Current worldwide production of cheese exceeds 20 million tonnes, including 633,500 tonnes of cheese produced in Poland (FAOSTAT, 2011). The number of cheeses available worldwide is very large and they not only serve to satisfy hunger

*This work was conducted as part of Ministry of Science and Higher Education project no. NN 311028334 . 
but are also consumed for pleasure, and some varieties are considered to be luxurious and sell at very high prices. Most commonly these are premium cheeses produced on the basis of milk obtained from native breed animals, such as Parmigiano-Reggiano cheese from the milk of Reggiana cows, Ragusano cheese from the milk of Modicana cows, and Roquefort cheese from Lacaune sheep milk (Litwińczuk, 2011).

Intensive selection of cattle for high milk yield in recent decades may have contributed to the reduction of biological value of raw material produced and also to the deterioration of its technological parameters. The research of Król et al. (2010) indicates that milk obtained from cows of local breeds is more abundant in functional whey proteins, such as $\alpha$-lactalbumin, $\beta$-lactoglobulin, lactoferrin and lysozyme. Furthermore, numerous studies reported that a large proportion of non-coagulating milk - from 1.3\% (Tyrisevä et al., 2004) to as much as 38\% (Okigbo et al., 1985 a, b) - was observed for highly productive breeds, in particular Holstein-Friesian cows. Conversely, milk from cows of local breeds is characterized by parameters favourable for processing, especially for cheese making (Chiofalo et al., 2000; De Marchi et al., 2007). This may result from the fact that local cattle breeds have retained numerous genes that determine product quality, which is desirable from the consumer's point of view. This is confirmed to a certain extent by the studies of Żurkowski et al. (2004) and Litwińczuk et al. (2006), which indicate that in highly productive cattle breeds, such as the Holstein-Friesian, some alleles have been irrevocably lost as a result of intensive selection.

The aim of the present study was to evaluate the nutritional value and technological suitability of milk from cows of three Polish breeds included in the genetic resources conservation programme.

\section{Material and methods}

The study included milk samples obtained from three Polish native cow breeds, namely White-backed (BG), Polish Red (RP) and Polish Black-and-White (ZB) raised under conventional conditions. The reference group consisted of milk from Polish Holstein-Friesian cows (PHF) maintained in the intensive system and milk from Simmental cows (SM) kept under conventional conditions.

Cows of the White-backed breed were maintained on 24 farms located in the area of Bug, Biebrza and Narew Rivers, whereas cows of the Polish Black-White breed were held on 11 farms from the same region. Polish Red cows were maintained in the Beskid Niski region in 14 barns, and Simmental cows were kept on 12 farms from the Bieszczady region. PHF cows were maintained in eastern Poland in six free-stall barns and fed on TMR (Total Mixed Ration) diets that consisted of maize silage, ensiled hay and commercial concentrate. Animals of other breeds were fed conventionally. The summer feeding consisted mainly of grazing on the pasture, whereas feeding in the winter season included hay, ensiled hay and optionally fodder beets or potatoes, and concentrated feed produced on the farm. All farms were milk recorded. 
Milk samples were collected on each farm, individually from cows in $2 \mathrm{nd}$, 3rd or 4th lactation (between 30th and 240th days of lactation) twice a year, namely in the summer and winter production seasons (in total of collection milk samples).

The following parameters were determined: basic chemical composition, i.e. contents of fat, protein, lactose and solids using Infrared Milk Analyser (Bentley Instruments); casein concentration by Walker's method (according to PN 68/A-86122); active acidity ( $\mathrm{pH}$ value) using a Pioneer $65 \mathrm{pH}$ meter (Radiometer Analytical); heat stability at $140^{\circ} \mathrm{C}$ in oil bath (TEWES-BIS) with White and Davies method (Barłowska, 2011); rennet coagulation time according to Schern's method, expressed as the time of formation of casein flakes (Barłowska, 2011); and concentration of whey proteins, i.e. $\alpha$-lactalbumin ( $\alpha$-LA), $\beta$-lactoglobulin ( $\beta$-LG), bovine serum albumin (BSA), lactoferrin and lysozyme - using reverse-phase high-performance liquid chromatography (RP-HPLC, Varian). The procedure of protein separation was based on a modified version of the method elaborated by Romero et al. (1996).

Additionally, 150 milk samples (30 samples per breed) were analysed for fatty acid profile (according to PN-EN ISO 5508:1996 and PN-EN ISO 5509:2001). The samples were selected randomly, observing the principle that each farm was represented. A Varian CG 3900 gas chromatograph with a flame-ionization detector (FID) was used. These analyses included the following groups of fatty acids:

- SFA - saturated fatty acids, SFAsmc - short and medium chain saturated fatty acids, including C4:0 to C14:0 acids, and SFAlc - long chain saturated fatty acids, including $\mathrm{C} 15: 0$ to $\mathrm{C} 18: 0$ acids;

- UFA - unsaturated fatty acids, including monounsaturated fatty acids (MUFA C10:1, C14:1, C15:1, C16:1, C17:1 and C18:1) and polyunsaturated fatty acids (PUFA - C18:2, C18:3 and CLA - conjugated linoleic acid).

A total of 209 samples of milk obtained from the cows of four breeds, i.e. PHF, $\mathrm{SM}, \mathrm{BG}$, and RP were analysed for macro- (Ca, Na, K and $\mathrm{Mg}$ ) and microelements (Fe, $\mathrm{Zn}$ ) by atomic absorption spectrometry with the use of Varian AA Duo spectrometer after microwave mineralization of samples with MarsXpress apparatus (CEM Corporation). After thawing the samples were agitated and a 1-ml milk sample was prepared. Then, the sample was flooded using $5 \mathrm{ml}$ of $65 \% \mathrm{HNO}_{3}$ acid. The maximum temperature of the mineralization was $190^{\circ} \mathrm{C}$.

The examinations included samples collected exclusively from animals with a healthy udder, namely with milk somatic cell count not exceeding 400,000 SC in $1 \mathrm{ml}$ of milk (Somacount 150 apparatus, Bentley Instruments).

The results obtained were analysed statistically using StatSoft Inc. software. STATISTICA ver. 6, on the basis of one-way ANOVA. Means and standard deviations were given for individual analysed traits, and the significance of differences between means was estimated by Fisher's LSD test at $\mathrm{P}=0.01$ level.

\section{Results}

The daily milk yield for cows of local breeds was $12.6 \mathrm{~kg}$ in Polish Red, 16.9 $\mathrm{kg}$ in White-backed, and $17.2 \mathrm{~kg}$ in Polish Black-and-White. On average, Sim- 
mental cows produced $19.1 \mathrm{~kg}$ of milk/day, and Holstein-Friesian cows yielded $25.9 \mathrm{~kg}$ of milk/day $(\mathrm{P} \leq 0.01)$. Milk from Holstein-Friesian cows was also characterized by a relatively high contents of basic components, i.e., fat, protein (including casein) and solids. Milk from cows of local breeds was generally characterized by a lower content of these components with the exception of cows of the Polish Red breed (Table 1). RP cows produced milk with a relatively high content of protein $(3.61 \%)$, including casein $(2.68 \%)$ and solids $(13.30 \%)$ $(\mathrm{P} \leq 0.01)$.

Table 1. Productivity and physicochemical parameters of milk from cows of analysed breeds

\begin{tabular}{|c|c|c|c|c|c|c|}
\hline \multirow{3}{*}{\multicolumn{2}{|c|}{ Item }} & \multicolumn{3}{|c|}{$\begin{array}{l}\text { Breeds included in the conservation of } \\
\text { genetic resources }\end{array}$} & \multicolumn{2}{|c|}{ Control group } \\
\hline & & $\mathrm{BG}$ & $\mathrm{RP}$ & ZB & \multirow{3}{*}{$\begin{array}{c}\text { SM } \\
\begin{array}{c}\text { (traditional } \\
\text { system) }\end{array} \\
329\end{array}$} & \multirow{3}{*}{$\begin{array}{c}\text { PHF } \\
\begin{array}{c}\text { (intensive } \\
\text { system) }\end{array} \\
219\end{array}$} \\
\hline & & \multicolumn{3}{|c|}{ (traditional system) } & & \\
\hline & $\mathrm{N}$ & 191 & 168 & 69 & & \\
\hline \multirow[t]{2}{*}{ Daily milk yield (kg) } & $\overline{\mathrm{x}}$ & $16.86 \mathrm{~B}$ & $12.59 \mathrm{~A}$ & $17.16 \mathrm{~B}$ & $19.11 \mathrm{C}$ & $25.86 \mathrm{D}$ \\
\hline & $\mathrm{SD}$ & 6.06 & 4.63 & 7.14 & 7.45 & 8.18 \\
\hline \multirow[t]{2}{*}{ Fat $(\%)$} & $\overline{\mathrm{x}}$ & $3.96 \mathrm{~A}$ & $4.35 \mathrm{~B}$ & $3.98 \mathrm{~A}$ & $3.93 \mathrm{~A}$ & $4.37 \mathrm{~B}$ \\
\hline & $\mathrm{SD}$ & 0.56 & 0.73 & 0.62 & 0.45 & 0.58 \\
\hline \multirow[t]{2}{*}{ Protein $(\%)$} & $\overline{\mathrm{x}}$ & $3.37 \mathrm{~A}$ & $3.61 \mathrm{~B}$ & $3.37 \mathrm{~A}$ & $3.38 \mathrm{~A}$ & $3.49 \mathrm{~B}$ \\
\hline & $\mathrm{SD}$ & 0.37 & 0.50 & 0.36 & 0.34 & 0.42 \\
\hline \multirow[t]{2}{*}{ Casein $(\%)$} & $\overline{\mathrm{x}}$ & $2.46 \mathrm{~A}$ & $2.68 \mathrm{C}$ & $2.46 \mathrm{~A}$ & $2.54 \mathrm{~B}$ & $2.59 \mathrm{~B}$ \\
\hline & $\mathrm{SD}$ & 0.41 & 0.41 & 0.37 & 0.33 & 0.38 \\
\hline \multirow[t]{2}{*}{ Protein-to-fat ratio } & $\overline{\mathrm{x}}$ & $0.86 \mathrm{~B}$ & $0.85 \mathrm{~B}$ & $0.86 \mathrm{~B}$ & $0.86 \mathrm{~B}$ & $0.81 \mathrm{~A}$ \\
\hline & $\mathrm{SD}$ & 0.11 & 0.17 & 0.10 & 0.09 & 0.09 \\
\hline \multirow[t]{2}{*}{ Lactose $(\%)$} & $\overline{\mathrm{x}}$ & $4.69 \mathrm{~B}$ & $4.66 \mathrm{~A}$ & $4.75 \mathrm{C}$ & $4.74 \mathrm{BC}$ & $4.75 \mathrm{C}$ \\
\hline & $\mathrm{SD}$ & 0.27 & 0.35 & 0.24 & 0.39 & 0.29 \\
\hline \multirow[t]{2}{*}{ Solids (\%) } & $\overline{\mathrm{x}}$ & $12.70 \mathrm{~A}$ & $13.30 \mathrm{~B}$ & $12.78 \mathrm{~A}$ & $12.73 \mathrm{~A}$ & $13.27 \mathrm{~B}$ \\
\hline & $\mathrm{SD}$ & 0.81 & 1.02 & 0.88 & 0.73 & 0.91 \\
\hline \multirow[t]{2}{*}{ Urea (mg/l) } & $\overline{\mathrm{x}}$ & $185.59 \mathrm{~A}$ & $177.93 \mathrm{~A}$ & $174.45 \mathrm{~A}$ & $216.40 \mathrm{~B}$ & $178.23 \mathrm{~A}$ \\
\hline & $\mathrm{SD}$ & 87.70 & 72.70 & 80.37 & 83.60 & 79.32 \\
\hline \multirow[t]{2}{*}{ Acidity (pH) } & $\overline{\mathrm{x}}$ & $6.72 \mathrm{~B}$ & $6.69 \mathrm{~A}$ & $6.74 \mathrm{~B}$ & $6.72 \mathrm{~B}$ & $6.73 \mathrm{~B}$ \\
\hline & $\mathrm{SD}$ & 0.10 & 0.13 & 0.07 & 0.08 & 0.07 \\
\hline \multirow{2}{*}{$\begin{array}{l}\text { Coagulation time } \\
(\mathrm{min})\end{array}$} & $\overline{\mathrm{x}}$ & $4.04 \mathrm{~B}$ & $3.09 \mathrm{~A}$ & $3.18 \mathrm{~A}$ & $3.20 \mathrm{~A}$ & $4.57 \mathrm{C}$ \\
\hline & $\mathrm{SD}$ & 2.05 & 1.18 & 1.37 & 1.07 & 2.06 \\
\hline \multirow[t]{2}{*}{ Heat stability (min) } & & $3.07 \mathrm{~B}$ & $2.4 \mathrm{~A}$ & $2.18 \mathrm{~A}$ & $3.01 \mathrm{~B}$ & $3.02 \mathrm{~B}$ \\
\hline & SD & 1.20 & 0.45 & 0.54 & 1.10 & 1.58 \\
\hline
\end{tabular}

$\mathrm{A}, \mathrm{B}, \mathrm{C}, \mathrm{D}-$ values in rows marked with different letters are significantly different at $\mathrm{P} \leq 0.01$. 
Milk from cows of local breeds was characterized by a significantly $(\mathrm{P} \leq 0.01)$ shorter time of rennet coagulation, mainly in the case of Polish Red (3:09 min) and Polish Black-and-White breeds (3:18 $\mathrm{min})$. The longest time of enzymatic coagulation (4:57 min) was characteristic of milk from PHF cows $(\mathrm{P} \leq 0.01)$. Milk from Polish Black-and-White cows (2:18 min) and Polish Red cows (2:34 min) had the lowest resistance to heat treatment (Table 1).

Table 2. The concentration of selected whey proteins in milk from cows of analysed breeds

\begin{tabular}{|c|c|c|c|c|c|c|}
\hline \multirow{3}{*}{\multicolumn{2}{|c|}{ Item }} & \multicolumn{3}{|c|}{$\begin{array}{l}\text { Breeds included in the conservation of } \\
\text { genetic resources }\end{array}$} & \multicolumn{2}{|c|}{ Control group } \\
\hline & & BG & $\mathrm{RP}$ & $\mathrm{ZB}$ & SM & PHF \\
\hline & & \multicolumn{3}{|c|}{ (traditional system) } & $\begin{array}{l}\text { (traditional } \\
\text { system) }\end{array}$ & $\begin{array}{l}\text { (intensive } \\
\text { system) }\end{array}$ \\
\hline & $\mathrm{N}$ & 191 & 168 & 69 & 329 & 219 \\
\hline \multirow[t]{2}{*}{$\alpha-\mathrm{LA}(\mathrm{g} / \mathrm{l})$} & $\overline{\mathrm{x}}$ & $1.03 \mathrm{AB}$ & $1.12 \mathrm{C}$ & $0.99 \mathrm{~A}$ & $1.04 \mathrm{~B}$ & $0.95 \mathrm{~A}$ \\
\hline & SD & 0.12 & 0.17 & 0.10 & 0.15 & 0.11 \\
\hline \multirow[t]{2}{*}{$\beta-\mathrm{LG}(\mathrm{g} / \mathrm{l})$} & $\overline{\mathrm{x}}$ & $3.69 \mathrm{D}$ & $3.18 \mathrm{~B}$ & $3.31 \mathrm{C}$ & $3.30 \mathrm{C}$ & $2.89 \mathrm{~A}$ \\
\hline & SD & 0.55 & 0.38 & 0.38 & 0.40 & 0.28 \\
\hline \multirow[t]{2}{*}{ BSA (g/l) } & $\overline{\mathrm{x}}$ & $0.40 \mathrm{~A}$ & $0.47 \mathrm{D}$ & $0.38 \mathrm{~A}$ & $0.39 \mathrm{~A}$ & $0.43 \mathrm{C}$ \\
\hline & SD & 0.16 & 0.13 & 0.11 & 0.14 & 0.14 \\
\hline \multirow[t]{2}{*}{ Lactoferrin $(\mathrm{mg} / \mathrm{l})$} & $\overline{\mathrm{x}}$ & $167.09 \mathrm{D}$ & $115.34 \mathrm{~B}$ & $143.98 \mathrm{C}$ & $151.15 \mathrm{C}$ & $90.77 \mathrm{~A}$ \\
\hline & SD & 60.12 & 32.83 & 43.97 & 51.87 & 22.09 \\
\hline \multirow[t]{2}{*}{ Lysozyme $(\mu \mathrm{g} / \mathrm{l})$} & $\overline{\mathrm{x}}$ & $8.85 \mathrm{~B}$ & $11.05 \mathrm{C}$ & $9.19 \mathrm{~B}$ & $10.14 \mathrm{C}$ & $5.94 \mathrm{~A}$ \\
\hline & SD & 7.05 & 4.94 & 4.75 & 7.25 & 2.38 \\
\hline
\end{tabular}

$\alpha$-LA - $\alpha$-lactalbumin; $\beta$-LG - $\beta$-lactoglobulin; BSA - bovine serum albumin.

$\mathrm{A}, \mathrm{B}, \mathrm{C}, \mathrm{D}$ - values in rows marked with different letters are significantly different at $\mathrm{P} \leq 0.01$.

Milk from cows of three local breeds and Simmental cows contained significantly $(\mathrm{P} \leq 0.01)$ more whey protein as compared to milk from Holstein-Friesian cows (Table 2). The highest content of $\beta$-lactoglobulin $(3.69 \mathrm{mg} / \mathrm{l})$ and lactoferrin (167.09 mg/l) among the local breeds was found in the milk of White-backed cows, whereas the greatest concentrations of $\alpha$-lactalbumin $(1.12 \mathrm{mg} / \mathrm{l})$ and lysozyme $(11.05 \mu \mathrm{g} / \mathrm{l})$ were observed in milk from Polish Red cows (Table 2).

Milk from cows of three local breeds and Simmental cows was characterized by a significantly greater $(\mathrm{P} \leq 0.01)$ proportion of polyunsaturated fatty acids (PUFA) as compared to milk from Holstein-Friesian cows (from $+1.29 \%$ for $\mathrm{BG}$ to $+2.32 \%$ for $\mathrm{RP})$. Corresponding relations $(\mathrm{P} \leq 0.01)$ were also found for CLA, the proportion of which in milk from Polish Red cows was almost seven-fold higher compared with milk from Holstein-Friesian cows. The latter was, however, characterized by significantly $(\mathrm{P} \leq 0.01)$ highest (by $4.52 \%$ on average) proportion of saturated fatty acids (Table 3 ). 
Table 3. Fatty acid profile of milk from cows of analysed breeds (\%)

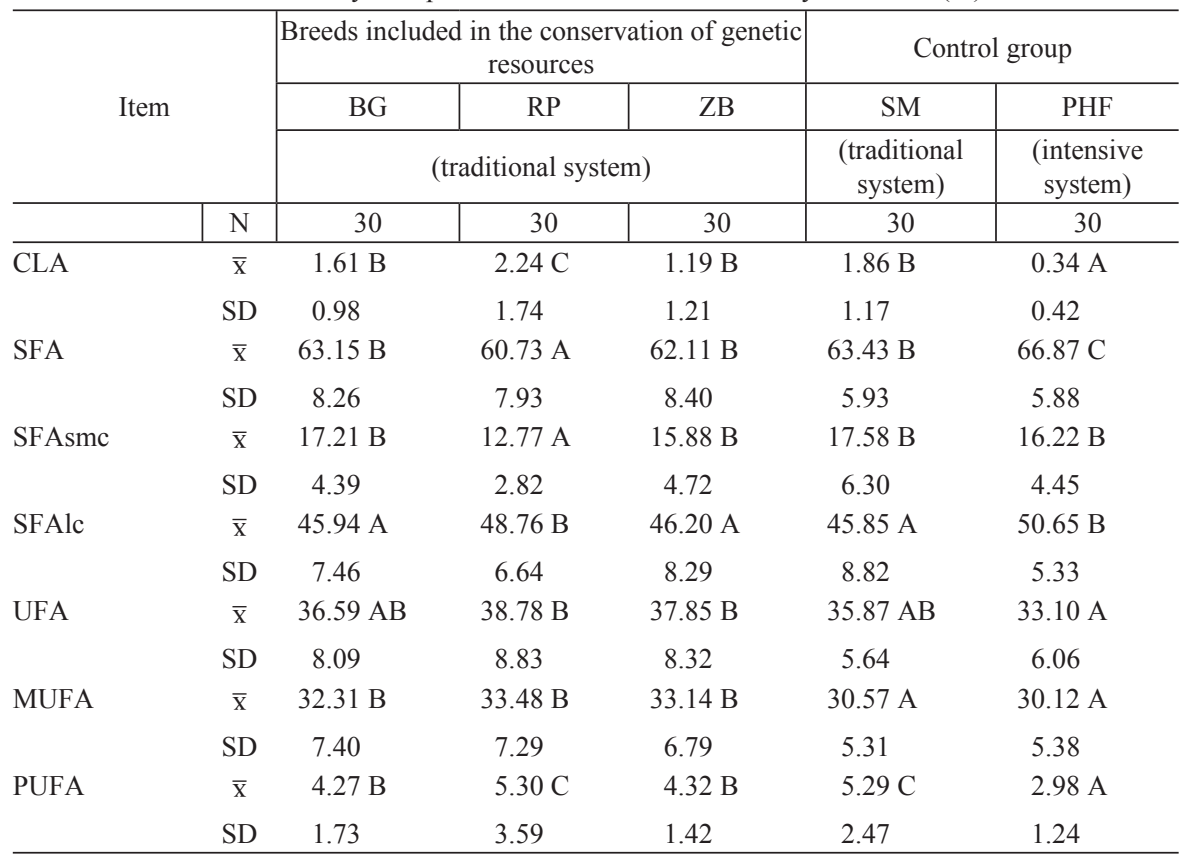

CLA - conjugated linoleic acid; SFA - saturated fatty acids, smc - short and medium chain, lc - long chain; UFA - unsaturated fatty acids, MUFA - monounsaturated fatty acids, PUFA - polyunsaturated fatty acids; A, B, $\mathrm{C}-$ values in rows marked with different letters are significantly different at $\mathrm{P} \leq 0.01$.

Table 4. The content of selected macro- and microelements in milk of cows of analysed breeds

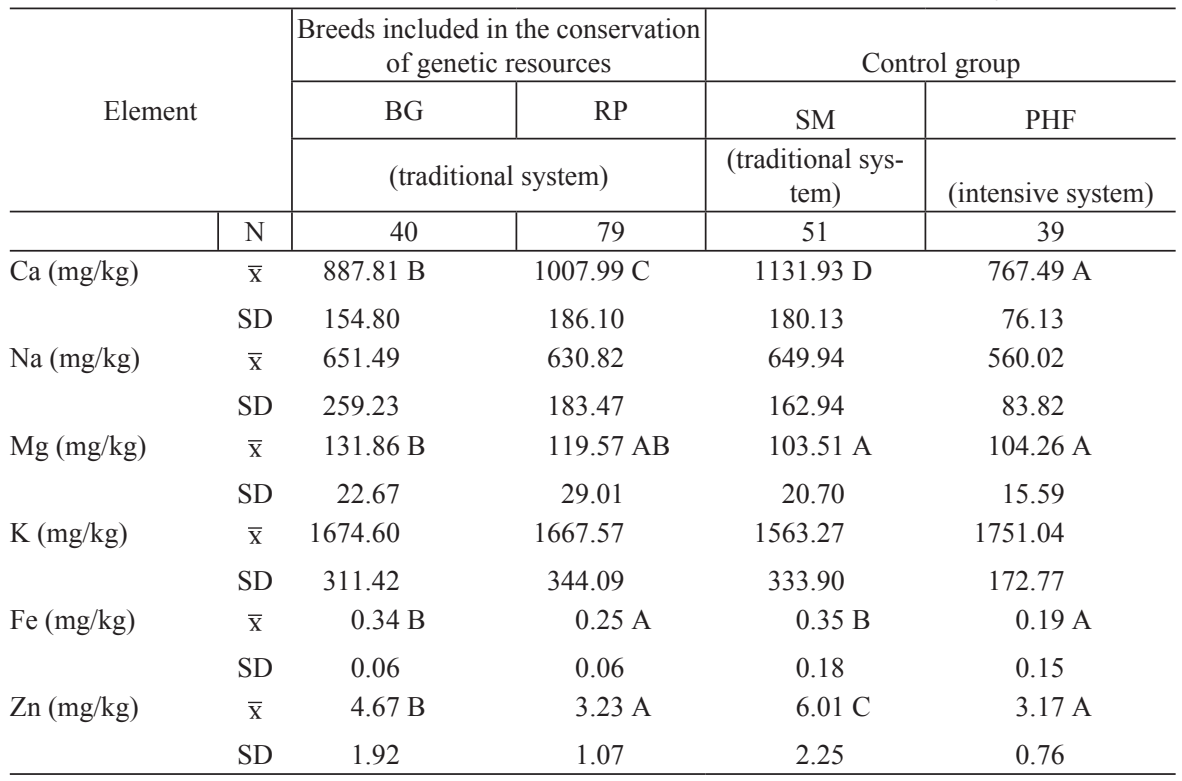

A, B, C, D - values in rows marked with different letters are significantly different at $\mathrm{P} \leq 0.01$. 
Milk from Holstein-Friesian cows had the lowest content of calcium $(767.5 \mathrm{mg} / \mathrm{kg})$, with significant $(\mathrm{P} \leq 0.01)$ differences in relation to milk from other investigated breeds. The highest concentration of calcium was determined in milk from Simmental $(1131.9 \mathrm{mg} / \mathrm{kg}$ ) and Polish Red cows $(1008.0 \mathrm{mg} / \mathrm{kg})$, whereas the highest content of magnesium in the milk of White-backed $(131.9 \mathrm{mg} / \mathrm{kg})$ and Polish Red cows $(119.6 \mathrm{mg} / \mathrm{kg})$. The highest contents of iron and zinc was observed in milk from Simmental cows (0.35 and $6.01 \mathrm{mg} / \mathrm{kg}$, respectively).

\section{Discussion}

The lower milk yield that is characteristic of local cow breeds is widely confirmed by many other studies (Barłowska and Litwińczuk, 2006; Chiofalo et al., 2000; Król et al., 2010; Litwińczuk, 2011). This may be explained by the fact that native breeds of cows, conversely to the Holstein-Friesian breed, do not possess a genetic predisposition for achieving high milk production. Furthermore, feeding of such breeds is mainly based on the fodder obtained from permanent pastures and other feeds obtained on the farm, which are not always fulfilling their nutritional requirements.

It is worth emphasizing the favourable protein-to-fat ratio in milk from cows of the breeds included in the genetic resources conservation and Simmental cows; this ratio was significantly $(\mathrm{P} \leq 0.01)$ higher as compared to the milk of Holstein-Friesian cows. It is an important indicator that determines the suitability of milk for cheese production. Guinee et al. (2007) claim that the most advantageous raw material for cheese production is milk with a protein-to-fat ratio of 0.85 and higher. Such ratio ensures the optimal yield and proper physicochemical parameters of cheese.

In relation to the results obtained, milk from Polish Red cows seems to be remarkably valuable, as the high content of fat (4.35\%) was concomitant with especially important high protein content (3.61\%), including casein (2.68\%). Moreover, the rennet coagulation time of RP milk was the shortest among five breeds investigated in the present study. This may be related to the distinctive origin of RP breed as compared to other analysed breeds. Polish Red cattle are considered to be descendants of small, wild brachyceros (short-horned) cattle, associated with the Slavic population for centuries. These uniform coloured cattle include also Czech Red (Moravian), Bavarian Red and Harz Red cattle (Konopiński, 1949). Publications of the last century (Konopiński, 1949; Pruski, 1975) were already indicating that cows of the RP breed (early 20th century), despite their lower productivity, produced milk with definitely higher content of fat that exceeded $5 \%$ in some individuals as compared to WesternFriesian cows, which were referred to as "Dutch cattle".

Two further analysed local breeds, namely White-backed and Polish Black-andWhite are derived from primigenius lowland cattle (Konopiński, 1949), similarly to the present Holstein-Frisian breed. This is confirmed by a recent review paper of Felius et al. (2011) conducted on the basis of numerous morphological, geographical and historical studies. Sixty years ago it was already highlighted (Konopiński, 1949) 
that milk fat from Polish Red cattle is characterized by a dominant proportion of large fat globules, which subsequently allows obtaining higher butter yield. Recent studies (Szarek et al., 2004) emphasize that milk from RP cows is characterized by parameters that are favourable for cheese production, predominantly due to the resultant higher yield of good quality casein curd, which is explained by a high proportion of allele B of $\kappa$-casein, characteristic of the RP breed. The results obtained in the present study indicate that milk from the analysed population of Polish Red cattle included in the genetic resources conservation programme was characterized by remarkably favourable parameters of nutritional value and technological suitability. Therefore, these results are an important argument in favour of continued implementation of this programme.

The rennet coagulation time of milk from cows of local breeds was significantly more favourable (i.e. shorter) as compared to milk from Holstein-Friesian cows, which was also reflected in the study of De Marchi et al. (2007), who compared parameters of milk suitability for cheese production, namely: coagulation time (r), curd formation time $\left(\mathrm{K}_{10}\right)$ and curd firmness $\left(\mathrm{A}_{30}\right)$ in five cattle breeds, including Holstein-Friesian and the local breed Rendena. The authors reported that the above parameters had the best values in the local breed Rendena $\left(r=13.5 \mathrm{~min}, \mathrm{~K}_{10}=5.9 \mathrm{~min}\right.$ and $\mathrm{A}_{30}=27 \mathrm{~mm}$ ) and the worst in the Holstein-Friesian breed $(\mathrm{r}=18.0 \mathrm{~min}$, $\mathrm{K}_{10}=8.2 \mathrm{~min}$ and $\mathrm{A}_{30}=17.5 \mathrm{~mm}$ ).

The higher content of whey proteins that was stated in milk from cows of local breeds corresponds with the findings of other authors (Grega et al., 2005; Król et al., 2010).

The significant $(\mathrm{P} \leq 0.01)$ differences that were demonstrated in the fatty acid profile of milk from cows of five studied breeds indicate that despite a similar (conventional) feeding system that was utilized for three breeds included in the genetic resources conservation and Simmental breed, cow breed is also a factor of variation within these parameters. The highest proportion of CLA was observed in milk from Polish Red cows $(2.24 \%)$, significantly lower proportion was determined in milk from Simmental (1.86\%), White-backed (1.61\%) and Polish Black-and-White $(1.19 \%)$, and the lowest $(0.34 \%)$ in milk of Polish Holstein-Friesian cows. The differences in milk fatty acid profile between cow breeds are also confirmed by other authors (Grega et al., 2005; Soyeurt et al., 2006; Soyeurt and Gengler, 2008). Nonetheless, the low level of CLA in milk from Holstein-Friesian cows should not be attributed exclusively to the influence of cow breed, because the main contributing factor is the feeding system (TMR). TMR system also contributes to the high content of fat, protein, casein and solids in milk of PHF cows. In the summer season cows of local breeds and Simmental cows grazed on the pasture, which could have a significant impact on the higher content of CLA in their milk (Schroeder et al., 2003).

Among various macro- and microelements contained in milk, calcium is the most important as it determines the nutritional value of milk and its technological suitability. Higher content of calcium in milk has a positive effect on the coagulation processes (Ziajka, 2008). It was also confirmed by the results of the present study. Milk from Holstein-Friesian cows was characterized by the lowest content of calcium and 
concomitantly the slowest rate of rennet coagulation. Conversely, milk of Polish Red and Simmental cows had the highest content of this element and simultaneously the highest rate of rennet coagulation. Nevertheless, the differences demonstrated in the contents of individual elements between analysed breeds cannot be solely associated with the cow breed influence. The analysed cow breeds were maintained in different regions of Poland; therefore, the concentrations of individual elements in soil as well as the intensity of soil mineral fertilization were very variable.

To conclude, it should be stated that the investigated cows of three breeds included in the genetic resources conservation programme produced milk with a higher nutritional value and more favourable parameters for processing as compared to cows of the PHF breed. Milk from Polish Red cows proved to be the most valuable in this respect, which can be associated with distinctive phylogenetic origin of this breed. Milk from cows of local breeds forms a marginal proportion of the raw material processed by the dairy industry, but it can be a valuable raw material for manufacture of regional and traditional products. Such products, when given the proper promotion, may become an important source of farm income. Further implementation of the genetic resources conservation programme for these breeds is therefore most reasonable.

\section{References}

B a rłow s k a J. (2011). Milk. In: Litwińczuk Z. (ed.), Methods of commodity evaluation of animal raw materials and products (in Polish). University of Life Sciences Publishing, Lublin, Poland, pp. 5-46.

B a rło s s ka J., L i tw iń c zuk Z. (2006). Technological usefulness of milk from two local breeds maintained in the regions with great grassland share. Arch. Tierzucht. (Dummerstorf), 49, Special Issue, 207-213.

Chiofalo V., Maldonato R., Martin B., Dupont D., Coulon J.B. (2000). Chemical composition and coagulation properties of Modicana and Holstein cows' milk. Ann. Zootech., 49: 497-503.

De Marchi M., Dal Z otto R., Cas sandro M., B ittante G. (2007). Milk coagulation ability of five dairy cattle breeds. J. Dairy Sci., 90 (8): 3986-3992.

FAOSTAT (2010). Statistics Division, 8.11.2011, http://faostat.fao.org/.

F e li us M., K o o lm e es P.A., Th e un is s en B. (2011). On the breeds of cattle - historic and current classifications. Diversity, 3: 660-692.

Grega T., S a d y M., N a j g e b a u er D., D o m a g a ła J., F a b e r B. (2005). Bioactive components of milk from different cow breeds. Biotechnol. Anim. Husb., 21 (5-6): 35-38.

Gu in e e T.P., Mulholland E.O., Ke 11 y J., C a 11 a g h a n D.J.O. (2007). Effect of protein-to-fat ratio of milk on the composition, manufacturing efficiency, and yield of cheddar cheese. J. Dairy Sci., 90: 110-123.

K o n o p iń s k i T. (1949). Cattle breeding (in Polish). Instytut Naukowo-Wydawniczy Ruchu Ludowego „Polska”, Poznań, Poland.

Kró 1 J., Li tw iń c zuk Z., B rodziak A., S aw i cka-Zugaj W. (2010). Bioactive protein content in milk from local breeds of cows included in the genetic resources conservation programme. Ann. Anim. Sci., 10 (3): 213-221.

L i tw iń c z u k Z. (2011). Editor. Conservation of genetic resources of livestock and wild animals (in Polish). PWRiL, Warsaw, Poland, p. 294.

Litwińczuk Z., Chabuz W., S tanek P., S aw i cka W. (2006). Genetic potential and reproductive performance of Whitebacks - Polish native breed of cows. Arch. Tierzucht. (Dummerstorf), 49: 289-296. 
Okigbo L.M., Richardson H., Brown R.J., Ernstrom C.A. (1985 a). Effect of pH, calcium chloride, and chymosin concentration on coagulation properties of abnormal and normal milk. J. Dairy Sci., 68 (10): 2527-2533.

O k i g b o L.M., R i c hard s o n H., B row n R. J., Ernstrom C.A. (1985 b). Variation in coagulation properties of milk from individual cows. J. Dairy Sci., 68 (4): 822-828.

Pruski W. (1975). Breeding of livestock animals in Galicia District in years 1772-1918 (in Polish). Zakład Narodowy im. Ossolińskich, Warsaw, Poland.

Romero C., Perez-Andujar O., Jimenes S. (1996). Detection of cow's milk in ewe's or goat's milk by HPLC. Chromatographia, 42: 181-184.

S chroed er G.F., D e l a ho y J.E., V i d a urret a I., B a rgo F., G a gli os tro G., Muller L.D. (2003). Milk fatty acid composition of cows fed a Total Mixed Ration or pasture plus concentrates replacing corn with fat. J. Dairy Sci., 86 (10): 3237-3248.

Soyeurt H., Dardenne P., Gillon A., Croquet C., Vanderick S., Mayeres P., Berto z zi C., Geng ler N. (2006). Variation in fatty acid contents of milk and milk-fat within and across breeds. J. Dairy Sci., 89: 4858-4865.

Soyeurt H., Gengler N. (2008). Genetic variability of fatty acids in bovine milk. Biotechnol. Agron. Soc. Environ., 12: 203-210.

Szarek J., A d a m c zy k K., F e leńc za k A. (2004). Polish Red cattle breeding: past and present. Agri, 35: 21-35.

T y r i s e vä A.-M., I k o n en T., O j a la M. (2003). Repeatability estimates for milk coagulation traits and non-coagulation of milk in Finnish Ayrshire cows. J. Dairy Res., 70: 91-98.

Z i a j k a S. (2008). Editor. Dairy technology. Part 1. (in Polish). UWM Olsztyn, Poland.

Żurkowski M., Niemczewski C., Zwierzchowski L., Zięba G., Litwińczuk Z. (2004). The determination of variation of genetic structure of Polish Red and White-backed cattle on the basis of polymorphism of 24 microsatellite DNA sequences. Pr. Mat. Zoot., 62: 59-72.

Accepted for printing 26 I 2012

\title{
ZYGMUNT LITWIŃCZUK, JOANNA BARŁOWSKA, WITOLD CHABUZ, ANETA BRODZIAK
}

\section{Wartość odżywcza i przydatność technologiczna mleka krów trzech polskich ras objętych programem ochrony zasobów genetycznych}

\author{
STRESZCZENIE
}

Badaniami objęto mleko trzech rodzimych ras krów, tzn. białogrzbietej (BG), polskiej czerwonej (RP) i polskiej czarno-białej (ZB) użytkowanych w tradycyjnym systemie chowu. Jako grupę odniesienia wykorzystano mleko krów rasy polskiej holsztyńsko-fryzyjskiej (PHF) użytkowanych w systemie intensywnym i mleko krów rasy simentalskiej (SM) z chowu tradycyjnego. W 976 próbach mleka oznaczono: zawartość tłuszczu, białka, kazeiny, laktozy i suchej masy, kwasowość (pH), stabilność cieplną, czas krzepnięcia mleka pod wpływem podpuszczki, zawartość $\alpha$-laktoalbuminy, $\beta$-laktoglobuliny, albuminy serum, laktoferyny i lizozymu. W pewnej części prób oznaczono także profil kwasów tłuszczowych oraz zawartość makro- i mikroelementów. Krowy ras rodzimych produkowały mleko o wyższej wartości odżywczej (więcej białek serwatkowych i wielonienasyconych kwasów tłuszczowych, w tym CLA) i lepszych parametrach do przetwórstwa w porównaniu do PHF. Najbardziej cenne pod tym względem było mleko krów rasy polskiej czerwonej, co można łączyć z innym pochodzeniem filogenetycznym tej rasy. Uzyskane korzystne parametry w zakresie wartości odżywczej i przydatności technologicznej mleka ocenianej populacji krów trzech ras objętych programem ochrony zasobów genetycznych są ważnym argumentem dla zasadności dalszej realizacji tych programów. 